\title{
YOUTH LEISURE ACTIVITIES: A SOCIOLOGICAL RESEARCH OF STUDENTS AT THE UNIVERSITY OF SPLIT (CROATIA)
}

\author{
Zorana Šuljug Vučica ${ }^{1}$, Gorana Bandalović ${ }^{2}$, Marija Lončar ${ }^{3}$ \\ ${ }^{1}$ Associate Professor, University of Split, Faculty of Humanities and Social Sciences (CROATIA), \\ zorana@ffst.hr \\ ${ }^{2}$ Associate Professor, University of Split, Faculty of Humanities and Social Sciences (CROATIA), \\ gbandalo@ffst.hr \\ ${ }^{3}$ Assistant Professor, University of Split, Faculty of Humanities and Social Sciences \\ (CROATIA), mloncar@ffst.hr
}

\begin{abstract}
The study of leisure is one of the most significant phenomena studied by sociology and other social sciences in recent decades. Leisure time can be defined as the time that a person has after fulfilling all his/her professional, familiar, social and physiological obligations, and creates it according to his/her own desires, possibilities and abilities. It is a particularly important segment of the daily life of young people as they are expected to arrange the most of their free time for their own growth and development.

Most authors who study the concept of leisure time emphasize that it must satisfy three functions in the life of young people: rest, leisure and personal development. Thus, leisure is the time that is set aside to fulfill one's personal needs and choices, which does not include the fulfillment of formal obligations. It should provide young people with fun, opportunities to socialize, to learn new skills, and to be active in the life of their local community. Therefore, most of them emphasize that leisure is an important distraction from stress and allows people to rest from everyday worries.

The aim of this research is to examine the ways in which students spend their leisure time and activities and how they arrange them according to their obligations at the faculty. Activities are divided into: sports, entertainment, cultural and educational. The specific aim of the research is to determine if there are statistically significant differences between male and female. The survey was conducted on a sample of 428 students of the University of Split at 12 different faculties during April 2019.

Most respondents have up to four hours of leisure time per day. There is a slightly higher percentage of those expressing dissatisfaction with the amount of free time. Almost all respondents surf the internet daily and spend time on social networks, while only a third of them watch television every day. Among other activities, students attend night clubs and cafes in the largest percentage, while almost half of the respondents attend cultural events (usually sport events, cinemas and concerts) only 1 to 2 times a year. A significant number of respondents are engaged in sports activities (such as recreational activities and going to the gym) daily or several times a week. There is also a significantly small number of respondents who spend their free time being engaged in additional educational activities (courses, workshops...).

Leisure time also includes interactions with other people. Respondents thus spend most of their free time interacting with friends on a daily basis and are extremely satisfied with their relationships with them. Finally, research has shown that leisure activities affect students' quality of life and their satisfaction with it.
\end{abstract}

Keywords: Leisure, activities, youth, students, sociological research. 
Proceedings of SOCIOINT 2020- 7th International Conference on Education and Education of Social Sciences,

\section{INTRODUCTION}

As a social phenomenon subject to change, leisure time is seen through many areas of life - social, pedagogical, economic, political, health, commercial and tourist (Vidulin-Orbanić, 2008, p. 19). In accordance with social, cultural, economic and technological changes, theoretical approaches and methodological research of free time and leisure have changed. The dominant approach in sociology sees free time as something that remains after performing socially obligatory work (Ilišin, 2017, p. 293). However, it is stated that in the analyzes it is also necessary to consider the influences of class affiliation and social status, education, sex and other situational circumstances on the free choice of leisure activities (Ilišin, 2017, p. 296). When it comes to the quality of free time, it is associated with rest, entertainment and personality development as its main functions (Dumazedier according to Ilišin, 2017, p. 295). Vidulin-Orbanić (2008) points out that, since it covers many aspects of contemporary life, free time is the research focus of various scientific disciplines.

By linking two concepts - free time and work, two ways of approaching to free time are recognized: free time as time left after socially obligatory work, which includes different family activities, additional work and so on, and free time as leisure time in which activities are solely freely selected (Dumazedier according to Ilišin, 2002, p. 271). People organize their free time after professional, family, social or physiological obligations and needs are fulfilled, and it is freely created according to one's own possibilities, abilities and desires (Vrkić Dimić, 2005, p. 314). In the understanding of free time, the attitude towards work as a non-free activity is therefore important (Polić and Polić according to Ilišin, 2014, p. 344). Although Ilišin makes difference between free time and leisure, she uses them as synonyms in her research of young people's free time. Among the reasons for that, she states the common use of the term free time, as well as the fact that most of the examined activities fall under leisure activities (Ilišin, 2014, p. 344). Thus, we here in this paper also use them at the same way.

Leisure time stands out as an important social phenomenon in relation to young people. This stems from the very characteristics of leisure time as well as of youth as a social group. They both have in common the dynamic that includes their susceptibility to the influences of the social environment (Ilišin, 2017, p. 293). In addition, free time is an important segment of the daily life of young people who are more exposed to various socialization influences, which is why they are expected to use the potential of free time for their own development (Ilišin, 2017, p. 313). The contents of free time enable young people to discover their potentials and interests, and develop abilities and acquire new knowledge, so it should be used in a quality way (Vrkić Dimić, 2005, p. 324). Regarding the research of spending free time, it is stated that among young people in Croatia there is a feeling of lack of time for leisure rather than a feeling of inappropriate use of free time (Ilišin, 2014, p. 347).

The dynamism of society and the development of technology affect the diversity in the structure of leisure use. Namely, the hedonistic way of life includes commercialization and culturally undesirable activities, whereby in the structure of young people's free time certain contents can become intrusive (Badrić and Prskalo, 2011, p. 481). Research on various aspects of leisure time suggests that it should enable young people to meet different needs. In addition, young people expect to use their free time for fun and socializing, learning new skills, and as the opportunity to be active in their local community (Bouillet, 2008, pp. 341-342). In other words, the empowerment and realization of young people and their interests (either individually or as groups) takes place through leisure activities (Jeđud and Novak according to Bouillet, 2008, p. 342). On the other hand, the development of society, technology and communication increase the space of free time for young people, and it is necessary to (freely) organize it (Vidulin-Orbanić, 2008, p. 21).

Organized free time for young people means getting to know different activities (scientific, artistic, sports...) and developing their individuality. On the other hand, free time is determined by social status, experience, habits, individual needs and opportunities of young people provided by the social environment (VidulinOrbanić, 2008, pp. 21). In this context, Vidulin-Orbanić emphasizes four needs of young people in the understanding of free time: the need for entertainment, for rest, for recreation and for the cultural aspect. Referring to some of the research conducted in the last 20 years, it is stated that young people most often spend their free time in social activities, while they are less involved in cultural and educational activities. The perceived urban cultural pattern in Croatia consists of fun activities such as going to clubs, parties, cafes and hanging out with friends. In addition to going out, young people often spend their free time in "passive" activities such as watching television, reading and listening to music (Vidulin-Orbanić, 2008, pp. 21).

Second need that can be understood as a passive leisure activity is rest, which serves to renew (re)productive force, and allows relax from the daily pace of life. This type of activity does not involve intensive intellectual effort, and one can rest by watching television or reading. Rush and numerous 
obligations are part of contemporary way of life, so it is not surprising that rest as an aspect of free time has almost disappeared. When it comes to the need for recreation, it is emphasized that the involvement of young people in various activities has a quality impact on their individual development. The most common activities in which young people are involved are sports, cultural, artistic, technical and the like activities offered by various institutions, associations and organizations. However, it is recognized that young people are more interested in activities aimed at personal pleasure, socializing and entertainment, and less in engagements that require any form of investment (intellectual, physical...) (Vidulin-Orbanić, 2008, p. 22).

Finally, the need for the cultural aspect of leisure time is underlined, and it is observed within cultural and artistic activities. Organized cultural and artistic activities, among other things, teach young people about the culture of spending free time, thus contributing to personal and social ways of life. Leisure culture refers to the aspect of using free time through learning and training, personal development and creative contribution. Accordingly, free time allows the development of the personality of young people intellectually and emotionally. It is, therefore, time for the development of their disposition, for critical reflection, creation, personal upgrading, as well as a time for cultural contribution and the promotion of a culture of living (VidulinOrbanić, 2008, p. 24). According to Vidulin-Orbanić (2008), the schools can educate young people about the culture of spending free time through adequate extracurricular activities

Ilišin points out that young people today are more preoccupied with fun activities, and less with those that contribute to the cultivation of free time. The structuring of leisure activities in the youth population remained relatively stable, but there were changes in the intensity of participation in leisure activities. Only in some activities did participation among young people increase, while participation in most of the surveyed activities decreased, which indicates certain changes in priorities. This is indicated by the increase in the time that young people dedicate to new technologies, which in the same time goes with a kind of passivation in those areas that have the potential to raise the quality of everyday life. According to lišin, it can be (their) response to the social crisis, adaptation to the requirements of contemporary society or passing trend. However, the impression remains that today's young people spend poorer leisure time regarding the content (llišin, 2017, p. 314).

\section{METHODOLOGY}

\subsection{Research Objectives and Hypothesis}

The aim of this research is to examine the ways in which students at the University of Split spend their leisure time and how they arrange their activities according to the obligations at the faculty. Activities are divided into: sports, entertainment, cultural and educational activities. The specific aim of the research is to determine if there are statistically significant differences between male and female students or between the students of different faculties regarding the aspects of leisure. According to the aims, specific hypotheses are set:

$\mathrm{H} 1$ - There is a difference in doing sport activities in free time regarding gender.

$\mathrm{H} 2$ - Male and female students differ in the amount of time which they spend by doing entertainment activities.

H3 - There is a difference between male and female students regarding frequency of visiting cultural institutions.

H4 - Male and female students differ in the amount of free time dedicated to educational activities.

\subsection{Method and Sample}

The research was conducted using a survey method on a convenience sample of 428 students at the University in Split. The field phase of the research was conducted in March and April 2019. According to the official website of the University of Split, the number of students is over $20000^{\circ}$, while the sample of our research included $2 \%$ or 428 students of the University of Split. Students who participated in the research attend one of the following faculties/academies: Faculty of Economics, Faculty of Electrical Engineering, Mechanical Engineering and Naval Architecture, Faculty of Philosophy, Faculty of Civil Engineering, Architecture and Geodesy, Catholic Faculty of Theology, Faculty of Chemistry and Technology, Faculty of Kinesiology, Faculty of Medicine, Faculty of Maritime Studies, Faculty of Law, Faculty of Science and Academy of Arts.

\footnotetext{
${ }^{1}$ https://www.unist.hr/sveuciliste
} 


\subsection{Sociodemographic Characteristics of Respondents}

Regarding the sex, there are 206 men (48,1\%) and 222 women (51,9\%) in the sample. The age structure is distributed in 12 categories in which the most represented respondents are in the categories of 20 years old $(23,6 \%)$ and 21 years old (28,5\%). The majority of respondents live in Split $(65,2 \%)$ and local areas and cities such as Kaštela (4,9\%), Šibenik (3,5\%), Solin $(3,0 \%)$ and other $(22,5)$. Regarding the housing of respondents, the largest number live with their parents in their apartment $(37,9 \%)$ or house $(25,9 \%)$. Other students live in hired flats $(26.6 \%)$ and student dormitory $(9,6 \%)$ at the University Campus. If we compare these data with data in neighboring countries, we can see similar results. According to for example EUROSTUDENT, living with parents is the most common form of housing in about two thirds of countries included in the research. In one third of EUROSTUDENT countries, the largest number of students live with their partner and/or children. Across countries, only 15,0\% of students live with others (outside student accommodation). On the other hand, living alone (outside student accommodation) is the rarest housing situation in EUROSTUDENT countries. Thus, only one out of ten students does not share his/her living space. Around $18 \%$ of students live in student accommodation. Regarding the older age groups of students, the number of those living with partner increases, and the number of those living with their parents or in student accommodation is lowered (Hauschildt, Vögtle, Gwosć, 2018, pp. 198-199). Regarding the respondents' satisfaction with housing, they are mostly satisfied with the location of the apartment $(69,6 \%)$, which includes lighting, heating, etc., and least satisfied with the environment $(54,4 \%)$, which includes greenery, parks, etc.

Most of the respondents are full-time students. Therefore, more than half of them (65\%) do not work, a little less than one third (30\%) work occasionally and only $4,9 \%$ of them work permanently. Accordingly, the major source of monthly income of respondents is pocket money from parents $(81,3 \%) .34,6 \%$ of them also have scholarship and $40 \%$ of them earn money. None of respondents uses disability benefits as a source of monthly income.

According to the sources from which they finance themselves, respondents' incomes are small. The incomes for $23,6 \%$ of students are less than 1000 HRK (133 euros) per month. For a little less than half of the students (47\%) the monthly income is $1001-2000$ HRK (133-266 euros). $22,9 \%$ of students have a monthly income from 2001 to 3000 HRK (266-400 euros) and only 6,5\% of them have an income of more than 3001 HRK (400 euros). By considering their monthly income, most of the students $(57,2 \%)$ estimate that they need additionally up to $1000 \mathrm{HRK}$ per month to cover costs. If we compare our data with EUROSTUDENT, we can conclude that data are quiet similar. At least a quarter of students have (very) serious financial difficulties. In all countries, more than $60 \%$ of students face moderate financial difficulties. From a macro perspective, the total monthly income of students comes from family/partner contribution (47\%), student self-employment $34 \%$, state student support 14\% and 5\% from other sources of income (Hauschildt et al., 2018, pp. 146-147).

\section{RESULTS AND DISCUSSION}

The amount of free time is divided into 3 categories (up to 4 hours, 4 to 8 hours and 8 and more hours). According to the survey, $63,1 \%$ of students have up to 4 hours of free time per day, $28,7 \%$ have 4 to 8 hours of free time and $8,2 \%$ have 8 or more hours of free time. We can compare this with the research "Needs, problems and potentials of young people in Croatia", conducted in the period from 2014 to 2017 . Almost three quarters of young people in 2013 had 3 or more hours of free time a day, which is slightly more than in the previous period (Ilišin, 2017, p. 298). Some research conducted in Croatia in the last fifteen years show students' dissatisfaction with the amount of free time and the way they spend their free time. For example, similar results were obtained in a survey on "Social position, problems and needs of young people in Zagreb County" in 2006 conducted by the Institute for Social Research in Zagreb. Namely, their results show that only a third of young people in Zagreb County are satisfied with their free time, which is not a large percentage considering that it should be time for their own interests and content (Ilišin, 2006, p. 314). Furthermore, in the research conducted at the Lavoslav Ružička Polytechnic in Vukovar, the goal was to determine the students' free time and how they spent it. There were 158 students who participated. Among them there were 36,71\% who answered that they did not have free time (Pejić, 2008, p. 347).

Regarding the way they spend their free time, the obtained data show that almost all respondents surf the internet daily $(97,9 \%)$ and spend time on social networks $(90,0 \%)$, while only a third $(35,5 \%)$ of them watch television every day. Although $42,3 \%$ of students have reading habits, there is a significantly small number of respondents who spend their free time being engaged in additional educational activities (courses, workshops...). As for the other activities, half of students $(49,5 \%)$ go to cafes every day, to nightclubs $(52,6 \%) 1-2$ times a month and $54,2 \%$ of them shop $1-2$ times a month. At the same time, a significant 
Proceedings of SOCIOINT 2020-7th International Conference on Education and Education of Social Sciences, 15-17 June 2020

number of respondents $(56,5 \%)$ are engaged in sports activities daily or several times a week.

Table 1. The frequency of doing different activities in free time

\begin{tabular}{|c|c|c|c|c|c|c|c|c|c|c|}
\hline \multirow[t]{2}{*}{$\begin{array}{l}\text { FREQUENCY OF DOING } \\
\text { DIFFERENT ACTIVITIES }\end{array}$} & \multicolumn{2}{|c|}{ Every day } & \multicolumn{2}{|c|}{$\begin{array}{l}1-2 \text { times per } \\
\text { week }\end{array}$} & \multicolumn{2}{|c|}{$\begin{array}{l}1-2 \text { times } \\
\text { monthly }\end{array}$} & \multicolumn{2}{|c|}{$\begin{array}{l}1-2 \text { times } \\
\text { yearly }\end{array}$} & \multicolumn{2}{|c|}{ Never } \\
\hline & $f$ & $\%$ & $f$ & $\%$ & $f$ & $\%$ & $f$ & $\%$ & $f$ & $\%$ \\
\hline 1. I attend cultural events. & 17 & 4,0 & 30 & 7,0 & 109 & 25,5 & 184 & 43,0 & 88 & 20,6 \\
\hline $\begin{array}{l}\text { 2. I educate myself } \\
\text { additionally (courses, } \\
\text { workshops ...). }\end{array}$ & 17 & 4,0 & 41 & 9,6 & 59 & 13,8 & 138 & 32,2 & 172 & 40,2 \\
\hline 3. I watch TV. & 152 & 35,5 & 146 & 34,1 & 72 & 16,8 & 14 & 3,3 & 44 & 10,3 \\
\hline 4.I surf the Internet. & 419 & 97,9 & 8 & 1,9 & 0,0 & 0,0 & 0 & 0,0 & 1 & 0,2 \\
\hline $\begin{array}{l}\text { 5. I spend time on social } \\
\text { media. }\end{array}$ & 385 & 90,0 & 27 & 6,3 & 11 & 2,6 & 3 & 0,7 & 2 & 0,5 \\
\hline 6. I read. & 181 & 42,3 & 106 & 24,8 & 72 & 16,8 & 50 & 11,7 & 19 & 4,4 \\
\hline 7. I go out to nightclubs. & 14 & 3,3 & 69 & 16,1 & 225 & 52,6 & 82 & 19,2 & 38 & 8,9 \\
\hline 8. I go to cafes. & 212 & 49,5 & 161 & 37,6 & 48 & 11,2 & 3 & 0,7 & 4 & 0,9 \\
\hline 8. I go shopping. & 20 & 4,7 & 76 & 17,8 & 232 & 54,2 & 88 & 20,6 & 12 & 2,8 \\
\hline 9. I do sports. & 119 & 27,8 & 123 & 28,7 & 85 & 19,9 & 48 & 11,2 & 53 & 12,4 \\
\hline 10. I do housework. & 185 & 43,2 & 173 & 40,4 & 48 & 11,2 & 16 & 3,7 & 6 & 1,4 \\
\hline
\end{tabular}

Data from previous research show similar results. According to the research conducted by llišin, Bouillet, Gvozdanović, and Potočnik (2013) on a representative sample of young people ( $N=1500)$ of the Republic of Croatia aged $14-27$, half $(54,3 \%)$ of them spent their free time watching television, slightly less than one third $(30,1 \%)$ were involved in sports and read books/newspapers $(26,7 \%)$. At the same time, the results of a survey conducted on a representative sample of young people $(N=1500)$ in the Zagreb County (llišin, 2006) showed that most young people $(69,3 \%)$ often watched television, less than half $(46,8 \%)$ of them sometimes read books and often read daily and/or weekly newspapers (45,7\%). A quarter $(24,6 \%)$ often and sometimes a third $(31,1 \%)$ of young people were engaged in sports. Also, a third $(34,2 \%)$ of them often and sometimes a half of young people $(54,2 \%)$ in Zagreb County went shopping.

As we were interested in the differences between male and female students in terms of the frequency of practicing certain activities, the hypothesis $\mathrm{H} 2$ was set up. It assumed that male and female students differed in the amount of time spent by doing entertainment activities. The chi-square test showed that there was a statistically significant difference in the frequency of visits to cafes according to gender $(x 2=14,170$; $d f=4$; $\mathrm{p}=0,007)$. Male students $(56,3 \%)$ more than female students $(43,2 \%)$ visit cafes every day, while female students $(42,3 \%)$ visit cafes $1-2$ times a month to a greater extent than male students $(32,5 \%)$. There is a statistically significant difference regarding gender in the frequency of shopping $(x 2=22,781 ; d f=4 ; p=0,000)$, with female students $(63,5 \%)$ more likely to go shopping than male students $(44,2 \%)$. It is usually $1-2$ times a month. Also, there is a statistically significant difference in the time students spend on social networks $(x 2=13,186 ; d f=4 ; p=0,010)$. Female students $(54,0 \%)$ to a slightly greater extent than male students $(46,0 \%)$ spend time on social networks every day, while male students $(70,4 \%)$ are much more likely than female students $(29,6 \%)$ to spend time on social networks 1-2 times a week. Although the differences regarding gender are recorded on three variables out of the nine tested, we still consider them important in the context of the topic of this paper, so the $\mathrm{H} 2$ hypothesis is partially accepted. At the same time, hypothesis $\mathrm{H} 4$ assumes that male and female students differ in the amount of free time dedicated to educational 
activities. A chi-square test was performed, but no statistically significant difference was found on the examined variables. Therefore, this hypothesis is rejected. Since a significant number of respondents $(56,5 \%)$ is engaged in sports activities daily or several times per week, further analysis of the frequency of engaging in sports activities shows that less than half (43,0\%) of students sometimes ride a bicycle, $41,4 \%$ of them are recreationally engaged in sport activities and $32,7 \%$ of them go to the gym. If these activities are considered in the category of "often doing sport", it is evident that the percentages are lower, with only a third $(31,3 \%)$ of students recreationally engaged in sports and a quarter of them $(24,3 \%)$ who go to the gym.

Table 2. The frequency of doing different sports

\begin{tabular}{|l|r|c|r|r|r|r|}
\hline \multirow{2}{*}{$\begin{array}{l}\text { THE FREQUENCY OF DOING } \\
\text { DIFFERENT SPORTS }\end{array}$} & \multicolumn{2}{|c|}{ NEVER } & \multicolumn{2}{c|}{ SOMETIMES } & \multicolumn{2}{c|}{ OFTEN } \\
\cline { 2 - 7 } & \multicolumn{1}{c|}{$f$} & \multicolumn{1}{c|}{$\%$} & \multicolumn{1}{c|}{$f$} & \multicolumn{1}{c|}{$\%$} & $f$ & \multicolumn{1}{c|}{$\%$} \\
\hline 1. I drive a bicycle. & 191 & 44,6 & 184 & 43,0 & 53 & 12,4 \\
\hline 2. I'm rolling. & 341 & 79,7 & 73 & 17,1 & 14 & 3,3 \\
\hline 3. I go to the gym. & 184 & 43,0 & 140 & 32,7 & 104 & 24,3 \\
\hline 4. I play sports professionally. & 350 & 81,8 & 33 & 7,7 & 45 & 10,5 \\
\hline 5. I do recreational sports. & 117 & 27,3 & 177 & 41,4 & 134 & 31,3 \\
\hline
\end{tabular}

Regarding the previously stated, we were interested in gender differences, so hypothesis $\mathrm{H} 1$ assumed that there was a difference in spending free time by doing sports activities regarding gender. Although roller skating is practiced by a small number of students $(17,1 \%$ of students sometimes do that), a chi-square test revealed a statistically significant difference regarding gender $(x 2=20,616 ; d f=2 ; p=0,000)$. A significantly higher number of female students $(71,4 \%)$ in comparison to male students $(28,6 \%)$ practice this sport activity. As we found statistically significant difference on only one of the six examined variables, this hypothesis was rejected.

Furthermore, an attempt was made to investigate how satisfied students in Split were with the city's cultural offer. The data show that the majority $(60,5 \%)$ of Split students are partially satisfied.

\section{Table 3. Respondents' satisfation with the cultural events offer in the city of Split}

\begin{tabular}{|l|r|c|}
\hline Cultural events offer & \multicolumn{1}{c|}{$f$} & $\%$ \\
\hline Yes, completely & 78 & 18,2 \\
\hline Partly & 259 & 60,5 \\
\hline No & 91 & 21,3 \\
\hline Total & 428 & 100,0 \\
\hline
\end{tabular}

In this context, the frequency of visiting the institutions is also examined. We were interested in how often students went to the cinema, concerts, theater, museums and to sports events. The data show that students most often go to the cinema $(19,6 \%$ of them go often; $71,5 \%$ of them go sometimes) and to concerts $(7,0 \%$ of them go often; $68,9 \%$ of them go sometimes) and attend sports events $(20,8 \%$ of them often; $42,3 \%$ of them sometimes). On the other hand, more than a half of them never visit museums (62,9\%) and do not go to the theatre $(58,6 \%)$.

Table 4. Frequency of visiting institutions

\begin{tabular}{|l|c|c|c|c|c|c|}
\hline \multirow{2}{*}{$\begin{array}{l}\text { FREQUENCY OF } \\
\text { VISITING INSTITUTIONS }\end{array}$} & \multicolumn{2}{|c|}{ NEVER } & \multicolumn{2}{c|}{ SOMETIMES } & \multicolumn{2}{|c|}{ OFTEN } \\
\cline { 2 - 7 } & $f$ & $\%$ & $f$ & $\%$ & $f$ & $\%$ \\
\hline
\end{tabular}


Proceedings of SOCIOINT 2020- 7th International Conference on Education and Education of Social Sciences,

\begin{tabular}{|l|r|r|r|r|r|r|}
\hline 1. cinema & 38 & 8,9 & 306 & 71,5 & 84 & 19,6 \\
\hline 2. concerts & 103 & 24,1 & 295 & 68,9 & 30 & 7,0 \\
\hline 3. theater & 251 & 58,6 & 158 & 36,9 & 19 & 4,4 \\
\hline 4. museum & 269 & 62,9 & 144 & 33,6 & 15 & 3,5 \\
\hline 5.sport events & 158 & 36,9 & 181 & 42,3 & 89 & 20,8 \\
\hline
\end{tabular}

The results of previous research (Ilišin, 2006) have shown very similar results, with young people who like going to the cinema $(19,5 \%$ of them go often; $60,2 \%$ of them go sometimes) and to concerts $(12,9 \%$ of them go often; $54,7 \%$ of them go sometimes) and a smaller percentage of those who visit the theater $(4,8 \%$ of them do that often; $41,0 \%$ of them do that sometimes).

Accordingly, we were interested in gender differences, so hypothesis $\mathrm{H} 3$ assumed that there was a difference between male and female students regarding the frequency of visiting cultural institutions. The chisquare test revealed a statistically significant difference regarding gender in the frequency of theater attendance $(x 2=8,393 ; d f=2 ; p=0,015)$. Although respondents in general do not attend the theater much, further analysis show that female students $(41,9 \%)$ still go to the theater to a greater extent than male students $(31,6 \%)$, while $65,5 \%$ of male students versus $52,3 \%$ of female students almost never visit this institution. Also, the chi-square test shows that there is a statistically significant difference in the frequency of museum visits with regard to gender $(x 2=13,826 ; d f=2 ; p=0,001)$. Higher number of male students $(71,8 \%)$ than female students $(54,4 \%)$ never go to museums, while female students $(41,0 \%)$ visit this institution more often than male students (25,0\%). As gender differences were found on two of the four variables examined, this hypothesis was partially accepted.

In the study, we also examined respondents 'relationships with the people (friends, family members, neighbors, colleagues, partner, and roommate) they interact the most often. We were also interested in how much of their free time they spent interacting with these people. When asked about their satisfaction with these relationships, $90,9 \%$ of respondents said they were satisfied with their relationship with friends. Some other research in Croatia shows similar results. For example, in a survey conducted in 2010, students spent most of their free time with friends $(96,0 \%)$ and this had the greatest impact on their happiness and satisfaction (Brkljačić, Kaliterna Lipovčan, Tadić, 2012, p. 361). Furthermore, our research shows that 85,0\% of students are satisfied with relationships with family members, and a high percentage of satisfaction can also be noticed in the research of the author Bouillet (2014). Her research, also conducted on the population of Croatian students, shows that $31,1 \%$ of them are very satisfied, and $43,9 \%$ are quite satisfied with the relationship with family members (Bouillet, 2014, p. 36). Regarding relationships with other people, a little over half of the students in our study are satisfied with relationships with neighbors and colleagues. In considering the relationship with the partner and roommate, the respondents point out that they are satisfied with the relationship. But, it is noticeable that more than $40 \%$ of respondents do not have a partner and more than $50 \%$ do not have a roommate.

Examination of the frequency of spending free time with other people shows that $64,7 \%$ of respondents spend time with friends every day. Very small number of students $(4,9 \%)$ spend their free time in interaction with neighbors Furthermore, respondents sometimes spend their free time with colleagues (36,7\%) and family $(33,4 \%)$. Some other research, for example, show that students at least sometimes spend their free time with family. Thus, for example, the research of the author Brkljačić et al. show that $80 \%$ of students at least sometimes spend time with their family (Brkljačić et al., 2012, p. 361). This is perhaps due to the fact that lots of students study in different town and visit parents sometimes. The results also showed that students rarely or never spend their free time with neighbors $(79,3 \%$ of them).

\section{CONCLUSION}

Leisure is a social phenomenon influenced by the dynamism and development of society itself (VidulinOrbanić, 2008; Ilišin, 2017, Badrić and Prskalo, 2011), whose importance is evident when it comes to young people as a specific social group (Ilišin, 2017; Vrkić Dimić, 2005; Badrić and Prskalo, 2011; Bouillet, 2008; Vidulin-Orbanić, 2008). For understanding of free time, it is necessary to consider its contents and activities because different disciplines show theoretical and research interest in analyzing the affinity of young people to participate in them since free time allows spaces where young people can develop their individual and 
social potentials (Ilišin, 2017; Badrić and Prskalo, 2011, Bouillet, 2008; Vidulin-Orbanić, 2008). However, recent research on leisure time among young people indicate that young people in Croatia do not participate enough in such content which allows realization of such potentials (llišin, 2017). At the same time, for researchers of young people's free time, it remains a phenomenon that can offer the answer to the question of what needs young people have in contemporary society.

The paper presents the results of a research aimed at examining how students at the University of Split spend their free time. The results show that most students have 4 hours of free time a day and that a third of them are satisfied with that time. Every day, students spend most of their free time surfing the Internet and using social networks, while only a third spend their free time watching television. Students like to read, but do not devote time to additional education such as attending some workshops or courses. On the other hand, they are very fond of going to cafes, nightclubs and shopping. Gender differences are visible here in terms of certain activities, so male students are more inclined to visit cafes, while female students are more inclined to shop and spend time on social networks. At the same time, half of the respondents are engaged in sports activities, most often cycling and recreational sports as well as going to the gym.

According to the data, students are partially satisfied with the city's cultural offer, spending most of their free time in cinemas and on concerts, while they rarely visit museums and theaters. Also, they most often spend their free time with friends, colleagues and family members, and the vast majority of respondents express satisfaction with the mentioned relationships, especially those with friends and family.

Finally, we can conclude that the data about leisure activities of the students of the University of Split confirm some of the earlier insights into the ways of spending free time among young people. Namely, they spend their free time more in fun activities than in educational or cultural ones, with more frequent activities on social networks. At the same time, the results indicate a lack of satisfaction with the amount of free time. So, in future research it would be desirable to give even greater emphasis on the relationship between the amount of free time and engaging in certain activities.

\section{REFERENCE LIST}

1. Badrić, M., Prskalo, I. (2011). Participiranje tjelesne aktivnosti u slobodnom vremenu djece i mladih. Napredak, 152(3-4): 479-494. https://hrcak.srce.hr/82788

2. Bouillet, D. (2008). Slobodno vrijeme zagrebačkih studenata: prilika za hedonizam ili samoostvarenje. Sociologija i prostor, 46(3/4 (181/182)): 341-367. https://hrcak.srce.hr/31812

3. Bouillet, D. (2014). Neki aspekti obiteljskog života studenata. In Ilišin, V. (ed.) Sociološki portret hrvatskih studenata. Zagreb: Institut za društvena istraživanja. pp. 29-56.

4. Brkljačić, T., Kaliterna Lipovčan, Lj., Tadić, M. (2012). Povezanost između osjećaja sreće i nekih aspekata provođenja slobodnog vremena. Napredak: časopis za pedagogijsku teoriju i praksu. 153(34): 355-371. http://hrcak.srce.hr/138871

5. Hauschildt, K., Vögtle, E. M., Gwosć, C. (2018). Social and Economic Conditions of Student Life in Europe: EUROSTUDENT VI 2016 - 2018: Synopsis of Indicators. Bielefeld: W. Bertelsmann Verlag $\mathrm{GmbH} \&$ Co. KG.

6. Ilišin, V. (2002). Interesi i slobodno vrijeme mladih. In Ilišin, V., Radin, F. (eds.) Mladi uoči trećeg milenija. Zagreb: Institut za društvena istraživanja u Zagrebu. Državni zavod za zaštitu obitelji, materinstva i mladeži. pp. 269-302.

7. Ilišin, V. (2006). Slobodno vrijeme i kultura mladih. In Ilišin, V. (ed.). Mladi između želja i mogućnosti. Zagreb: Institut za društvena istraživanja u Zagrebu. pp. 299-328.

8. Ilišin, V., Bouillet, D., Gvozdanović, A., Potočnik, D. (2013). Mladi u vremenu krize. Prvo istraživanje IDIZa i Zaklade Friedrich Elbert o mladima. Zagreb: Institut za društvena istraživanja. Friedrich Elbeert Stiftung.

9. Ilišin, V. (2014). Zanemarena škola života: slobodno vrijeme i interesi studenata. In llišin, V. (ed). Sociološki portret Hrvatskih studenata. Zagreb: Institut za društvena istraživanja u Zagrebu. pp. 343375. 
10.llišin, V. (2017). Neke dimenzije slobodnog vremena mladih. In Ilišin, V., Spajić Vrkaš, V. (eds.). Generacija osujećenih: mladi u Hrvatskoj na početku 21. stoljeća. Zagreb: Institut za društvena istraživanja u Zagrebu. pp. 293-316.

11.Pejić, D. (2008). Ispitivanje mišljenja studenata o korištenju slobodnog vremena i subjektivnom doživljaju zdravlja na veleučilištu Lavoslav Ružička u Vukovaru. In Neljak, B. (ed.). Zbornik radova na temu stanje i perspektiva razvoja u područjima edukacije, sporta, sportske rekreacije i kineziterapije. Zagreb: Hrvatski kineziološki savez. pp. 346-353.

12. Vidulin-Orbanić, S. (2008). Fenomen slobodnog vremena u postmodernom društvu. Metodički obzori, 32(6): 19-33. https://hrcak.srce.hr/32748

13.Vrkić Dimić, J. (2005). Stvarne i željene aktivnosti studenata u slobodnom vremenu. Pedagogijska istraživanja, 2(2): 313-325. https://hrcak.srce.hr/139322 